\section{Breastfeeding and feeding patterns in three birth cohorts in Southern Brazil: trends and differentials}

\author{
Amamentação e padrões alimentares em três \\ coortes de nascimento no Sul do Brasil: tendências \\ e diferenciais
}

\author{
1 Programa de Pós-gradu- \\ ação em Epidemiologia, \\ Universidade Federal de \\ Pelotas, Pelotas, Brasil. \\ 2 Programa de Pós-graduação \\ em Saúde e Comportamento, \\ Universidade Católica de \\ Pelotas, Pelotas, Brasil. \\ Correspondence \\ C. G. Victora \\ Programa de Pós-gradu- \\ ação em Epidemiologia, \\ Universidade Federal de \\ Pelotas. \\ Rua Marechal Deodoro 1160 \\ 3o andar, Pelotas, RS \\ 96020-220, Brasil. \\ cvictora@terra.com.br
}

\begin{abstract}
Breastfeeding is fundamental for child health. Changes in the duration of breastfeeding are compared for three population-based cohorts of children born in 1982, 1993 and 2004 in the city of Pelotas, Southern Brazil. Samples of the 1982 and 1993 children and all of the children from the 2004 cohort study were sought at home when they were aged around 12 months. Both the duration of breastfeeding and the stage at which different kind of foods were regularly introduced were investigated. The median duration of breastfeeding increased from 3.1 to 6.8 months in this period. Exclusive breastfeeding at three months was practically non-existent in 1982 and had reached one third of infants by 2004. The increase was faster after 1993, suggesting an important impact made by promotion activities. Up to about 6-9 months, breastfeeding was more prevalent in high-income families, but after this age it became more common among the poor. Low birth weight babies were breastfeed for shorter durations. The duration of breastfeeding is still far short of international recommendations, justifying further campaigns. Special attention should be given to low birth weight babies and those from low-income families.
\end{abstract}

Breast Feeding; Child Welfare; Cohort Studies

\author{
Cesar G. Victora ${ }^{1}$ \\ Alicia Matijasevich 1 \\ Iná S. Santos 1 \\ Aluisio J. D. Barros 1 \\ Bernardo L. Horta 1 \\ Fernando C. Barros 2
}

\section{Introduction}

Breastfeeding plays an important role in child development, especially as a protective factor against infectious diseases 1,2 . In addition to such protection, breastfeeding also increases child spacing 3,4 and promotes ideal child growth 5 . Recent results also suggest that breastfeeding may contribute to intellectual development, as well as to the prevention of various chronic diseases in adult life ${ }^{6}$. The promotion of exclusive breastfeeding is the single intervention with the greatest potential to reduce under-five mortality worldwide 7 .

The duration of breastfeeding in Brazil was extremely short in the 1970s and 1980s. A nationwide survey carried out in 1975 showed that the median duration of total breastfeeding was only 74 days 8 . A series of interventions were implemented beginning in the 1980s, which led to important increases in the duration of breastfeeding during the 1990s 8,9.

Although a number of studies on breastfeeding have been conducted in Brazil, it is also important to analyze trends among different socioeconomic and birth weight strata. The present analysis evaluates changes in the duration of breastfeeding in the city of Pelotas, Rio Grande do Sul State, Brazil, based on three longitudinal studies of the mother-child population that began in 1982, 1993, and 2004. 


\section{Methods}

As part of the Pelotas birth cohort studies, we evaluated all hospital births that took place in 1982, 1993, and 2004. The methodology used in these studies has been described elsewhere 10 . Mothers were interviewed soon after delivery and, among other variables, provided information on total family income, which was calculated as the sum of individual incomes in the month preceding the interview. All children were weighed using calibrated pediatric scales.

At the beginning of 1983, we attempted to locate all children living in urban areas born between January and April 1982, who were then an average 12 months old. In the 1993 cohort, a sample of births was followed at ages six and 12 months, including all low birth weight children $(<2,500 \mathrm{~g})$ and a systematic sample of approximately $20 \%$ of the remaining children. Final results were weighted so as to reproduce the proportion of low birth weight in the general population observed in the perinatal study. In 2004, we attempted to locate all children around the time of their first birthday.

In the three studies, mothers responded to a household questionnaire administered by interviewers who received prior training and were educated to at least high-school level. Between five and 10 per cent of interviews were repeated by a supervisor for quality control purposes. The questionnaire included questions on the duration of breastfeeding and the ages at which different types of foods were introduced on a regular basis. Weaning was defined as the total interruption of breastfeeding.

To avoid recall bias, comparisons of weaning age and introduction of complementary feeding were based on data collected when children were approximately 12 months old.

The feeding patterns of children during the first year of life were classified into four groups: (i) exclusive breastfeeding - breastfed children that were not fed any other fluids or solid foods; (ii) predominant breastfeeding - breastfed children that were also fed other fluids, such as water or tea, but who were not fed solid or semi-solid foods; (iii) partial breastfeeding - children that were fed breast milk complemented with other types of milk, such as cow's milk or formula, or with solid or semi-solid foods; and (iv) weaning - children that were not breastfed.

In 1982, there was not a specific question regarding the ingestion of tea or water, since this was a universal practice at the time, with all children being given tea and water soon after birth. The advantages of exclusive breastfeeding became evident only in the late 1980s 11 . For the pur- poses of comparison, the prevalence of exclusive breastfeeding in 1982 was considered as null.

In each of the three cohorts, at least 1,300 children were included in the analyses. The margin of error for estimating the prevalence of breastfed children at each age was equal to or less than 2.5 percentage points.

We used the chi-squared test to measure associations between independent variables (sex, family income, and birth weight) and the duration of breastfeeding. Whenever possible, we used the linear trend test to study trends between the three cohorts.

Statistical analysis was carried out using Stata software (Stata Corp., College Station, USA) to calculate the percentage of breastfed children at different ages and to estimate the median duration of breastfeeding based on life tables.

\section{Results}

In 1983 , we traced 1,556 (81.8\%) of the 1,820 children born between January and April 1982, who were on average 11.2 months old (standard deviation 1.3 months). In 1993, we were able to trace $93 \%$ of children at age 12 months. In 2004, the follow-up rate was $94 \% 10$.

We found an increase in the median duration of breastfeeding from 3.1 months in 1982 to 4.0 months in 1993 and 6.8 months in 2004 (Table 1). Figure 1 shows that, although initially almost all children from the three cohorts were breastfed, an increase in breastfeeding in the more recent cohorts was already evident after the first month (linear trend test $\mathrm{p}<0.001$ in the first month and at ages 3, 6, 9, and 12 months). The greatest increase occurred between the 1993 and 2004 cohorts.

Figure 2 shows the feeding pattern of children at three and 12 months of age. Important progress was seen at age three months. In 1982, although specific information on the consumption of tea and water had not been collected, the practice of exclusive breastfeeding was virtually null. Such practice could already be observed in 1993, when $7 \%$ of children were exclusively breastfed. In 2004, this proportion increased to $31 \%\left(\chi^{2} \mathrm{p}\right.$ $<0.001)$. Predominant breastfeeding was seen in $34 \%$ of children in $1982,41 \%$ in 1993 , and $17 \%$ in 2003; such a reduction seems to have been due to the increase in exclusive breastfeeding. Considering all types of breastfeeding, $54 \%, 62 \%$, and $73 \%$ of three-month-old children were breastfed in 1982, 1994, and 2004, respectively ( $\chi^{2}$ for linear trend $\mathrm{p}<0.001)$.

Figure 2 also shows that, at age 12 months, $18 \%, 23 \%$, and $39 \%$ of children were still breast- 
Table 1

Median duration of breastfeeding according to sex, family income, and birth weight. Pelotas, Southern Brazil, 1982, 1993, and 2004.

\begin{tabular}{|c|c|c|c|}
\hline \multirow[t]{2}{*}{ Variables } & \multicolumn{3}{|c|}{ Median duration of breastfeeding (months) } \\
\hline & 1982 & 1993 & 2004 \\
\hline Sex & NS & $p<0.001$ & $p=0.04$ \\
\hline Male & 3.0 & 3.8 & 6.5 \\
\hline Female & 3.2 & 4.3 & 7.4 \\
\hline Family income (minimum wage) & $p=0,8$ & $p=0.5$ & $p=0.05$ \\
\hline$\leq 1.0$ & 2.9 & 3.9 & 5.8 \\
\hline $1.1-3.0$ & 2.9 & 4.1 & 7.0 \\
\hline $3.1-6.0$ & 3.3 & 3.7 & 6.8 \\
\hline $6.1-10.0$ & 3.6 & 3.6 & 7.8 \\
\hline$>10.0$ & 3.4 & 5.3 & 6.9 \\
\hline Birth weight (g) & $p<0.05$ & $p<0.0001$ & $p<0.001$ \\
\hline$<2,000$ & 1.8 & 1.4 & 3.7 \\
\hline $2,000-2,499$ & 2.1 & 3.1 & 5.7 \\
\hline $2,500-2,999$ & 3.0 & 4.0 & 6.8 \\
\hline $3,000-3,499$ & 3.0 & 4.1 & 7.2 \\
\hline$\geq 3,500$ & 3.5 & 4.5 & 6.8 \\
\hline Total & 3.1 & 4.0 & 6.8 \\
\hline
\end{tabular}

NS: non-significant.

Figure 1

Percentage of breastfed children at different ages. Pelotas, Southern Brazil, 1982, 1993, and 2004.

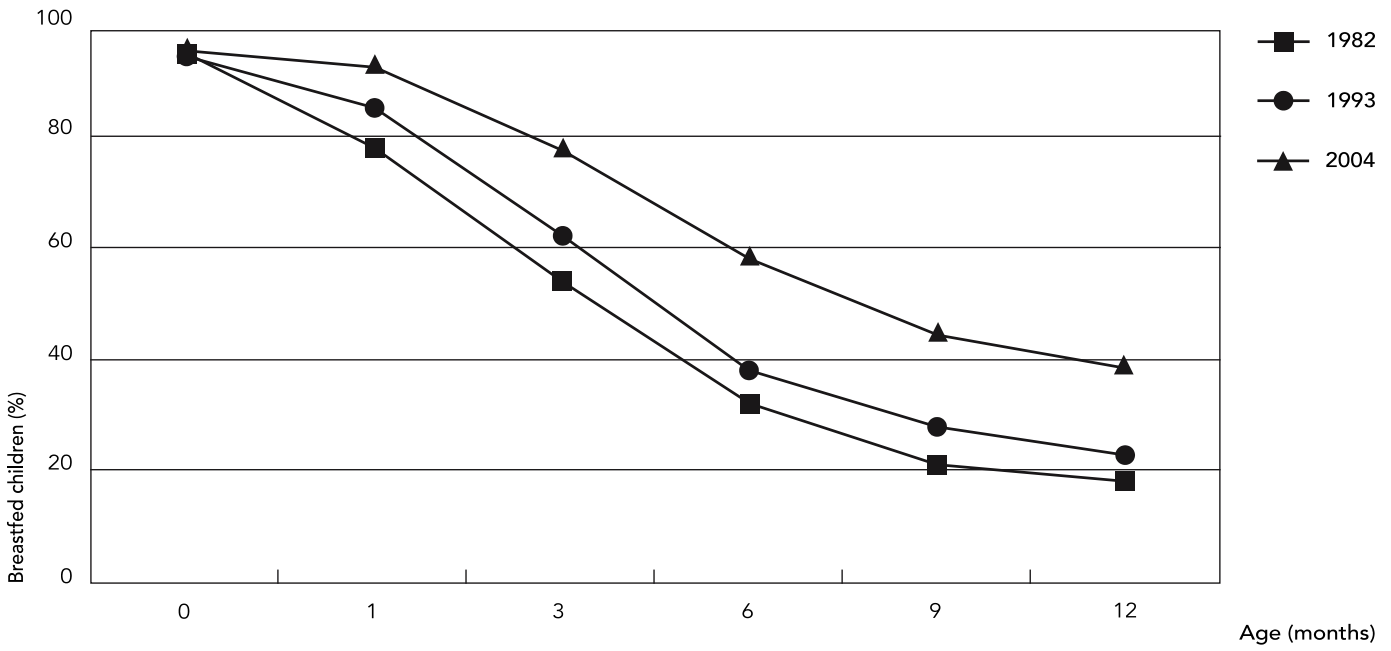




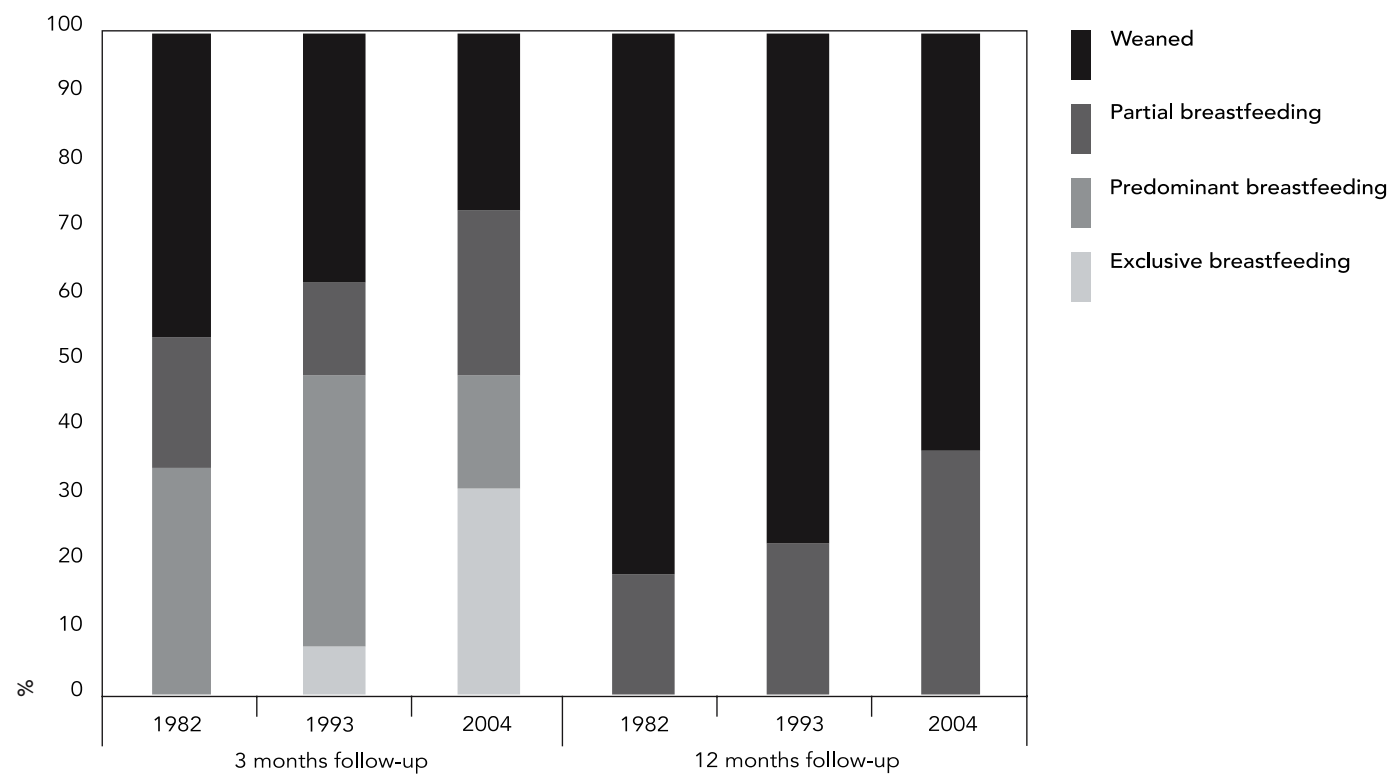

fed in 1982, 1993, and 2004 ( $\chi^{2}$ for linear trend $\mathrm{p}$ $<0.001$ )

However, feeding practices varied between different subgroups of children. Breastfeeding lasted longer for girls than for boys in 1993 and 2004 (Table 1). There were no marked differences in terms of median duration between family income groups (Table 1). However, as shown in Figure 3, there were some interesting changes among the poorer (people earning less than or equal to the minimum wage) and richer (those earning more than 10 times the minimum wage) strata. In the three cohorts, the richest group showed a greater prevalence of breastfeeding up to age six months but was overtaken by the poorest group between six and nine months, so that, at age 12 months, poor mothers breastfed more than rich mothers. Also noteworthy is the observation that the increase in breastfeeding frequency at ages one, three, and six months occurred between 1982 for the richest group and between 1993 and 2004 for the poorest. By contrast, the increase at age 12 months took place between 1993 and 2004 for both poor and rich groups.

We found a direct relationship between birth weight and duration of breastfeeding in the three studies, with a surprisingly short duration among the $<2,000$ g group, which was partially reversed in 2004 (Table 1). Breastfeeding increased throughout the two-decade period across all breastfeeding groups.

\section{Discussion}

The existence of three population-based cohort studies allowed for breastfeeding patterns to be compared across a 22-year time period. The percentage of follow-up at age 12 months increased from $79 \%$ in 1982 to $94 \%$ in 2004 due to the innovative strategies used in tracing subjects 10 .

We observed an important increase in the median duration of breastfeeding, from 3.1 months in 1982 to 6.8 months in 2004. 1982 levels were compatible with those observed throughout the country in that period 8 , but the median in 2004 is similar to the 7.0 month median reported in 1996 for the entire country (7.1 months in the South Region, in which Pelotas is located) 8,12. In 1999, a nationwide survey of state capitals was conducted during a vaccination campaign 13 , which resulted in an estimate of 9.9 months for all Brazilian capitals and 7.5 months for those in 


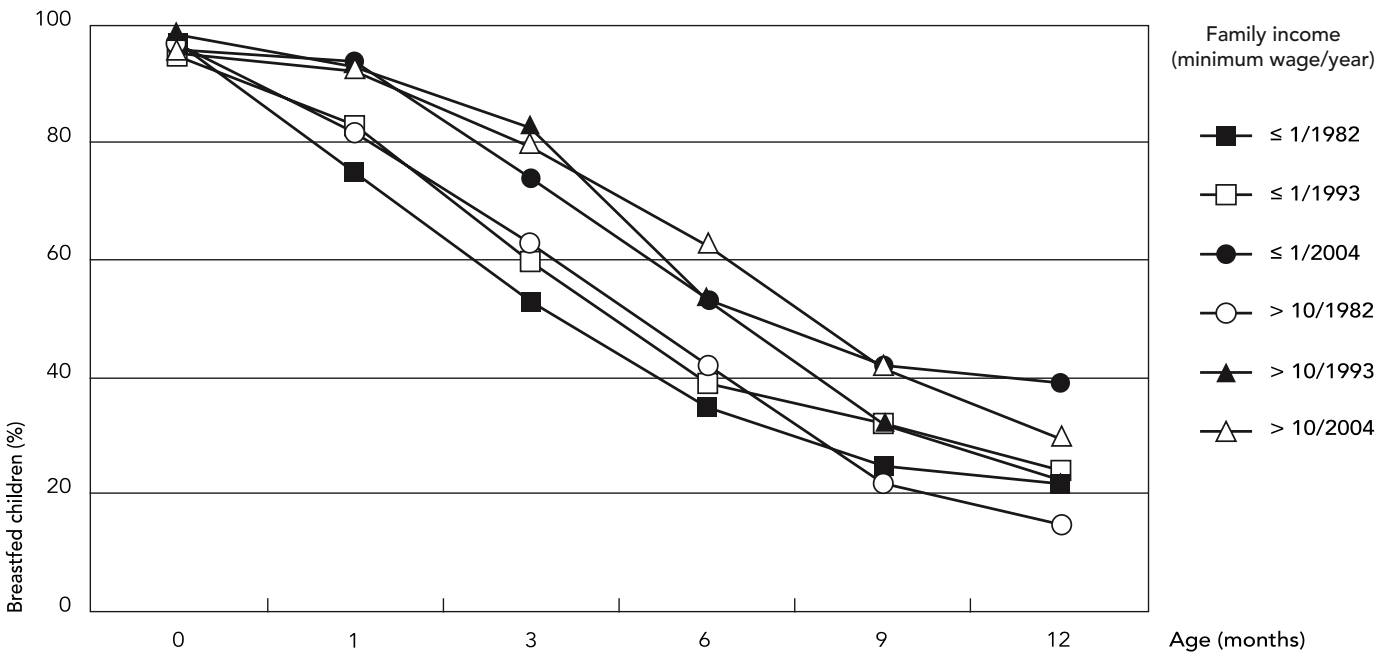

the South Region, which is similar to the median obtained for Pelotas in 2004.

The analysis of feeding patterns (Figure 2) shows that this increase is due to the increase in exclusive breastfeeding during the first few months of life, when its protective effects are greater 1,14 , as well as to an increase in partial breastfeeding during the second semester.

The introduction of fluids other than breast milk during the first months of life is not only unnecessary - since exclusively breastfed children do not need additional water - but it may also be deleterious 15 . The introduction of other fluids may lead to a decreased frequency and intensity of suction, thus reducing breast milk production. There is also the risk of infections due to the contamination of bottles or of the food itself. Moreover, the premature introduction of certain types of foods, such as cereals or vegetables, may interfere with iron absorption, leading to iron deficiency. Long-term risks, such as obesity, hypertension, arteriosclerosis, and food allergies may also be associated with the introduction of other foods and weaning 6 .

The World Health Organization and United Nations Children's Fund also recommend that partial breastfeeding be continued until age 2 years 11 . However, in 2004, only $39 \%$ of children were breastfeed at 12 months. Despite the substantial progress in the last decade, still less than half of all children in Pelotas were breastfed at their first birthday.

Countless factors influence the decision of whether or not to breastfeed, hindering the evaluation of the impact of breastfeeding promotion programs. Notwithstanding, the present data support a possible impact of the Brazilian National Breastfeeding Program, that has been carried out since 1981 across the entire country 9,16,17. Rea 9 , in an analysis of breastfeeding promotion activities throughout Brazil, showed that interventions begun in the 1980's were substantially reinforced after 1996, with the training of large numbers of health workers for supporting breastfeeding, backed-up by protection policies. In Pelotas, specifically, a number of training courses were offered to primary healthcare professionals, and the first "Baby-Friendly" hospital was opened in the city. The present results, which show an acceleration of the increase in breastfeeding duration after the 1993 cohort, are entirely compatible with the chronogram described by Rea 9 .

Data from the three cohorts confirm previous findings 18,19 regarding biological and socioeconomic differentials in breastfeeding. Gender differences in breastfeeding have been reported by others. In the present study girls were breastfed longer than boys, a finding also reported by other authors 20. Children from low-income families 
or with low birth weight, who most need breastfeeding, are those that receive less breast milk during the first months of life. The shorter duration of breastfeeding among low birth weight babies has been described previously ${ }^{4}$. Morbidity and mortality in low birth weight children is greater among formula-fed than among breastfed babies 21 .

Results regarding family income show a paradoxical relationship. High-income mothers breastfeed more during the first months of life than do low income mothers. This period of life is exactly when children are at greater risk of morbidity and mortality, especially those from poor families, as shown in other articles in the present supplement 22,23. Premature weaning among these children may be contributing to the increase in mortality and morbidity. On the other hand, there is a greater prevalence of breastfeeding among poor children at nine and 12 months of age.

In a previous publication, we proposed the hypothesis of inverse equity, that is, that innovations in health tend to reach the rich before they reach the poor, thereby potentially increasing social inequities 24 . Figure 3 shows that, in the highest income group, the increase in the percentage of breastfed children at ages one, three, and six months occurred mostly between 1982 and 1993. Among the poor, on the other hand, a similar increase took place between 1993 and 2004. This may be evidence that an increase in breastfeeding occurred earlier among the rich. Regarding the increase in the percentage of breastfed children at 12 months, both the rich and the poor showed greater increases predominantly after 1993, which may reflect the fact that the importance of breastfeeding during the second semester of life has been emphasized only more recently.

The susceptibility of breastfeeding to advertisements for artificial feeding is a well-known phenomenon. Between the 1950s and 1970s, when incentives for using formula feeding were substantial and there were no restrictive health policies regarding such advertisements, the duration of breastfeeding fell substantially in several countries 25 . More recently, campaigns encouraging breastfeeding and valuing breast milk led to the reversion of falling trends not only in Brazil 9 but also in Latin America 26. Despite these changes, the duration of breastfeeding, especially exclusive breastfeeding, remains substantially lower than international recommendations, which reinforces the need to continue stimulating this practice in the first months of life. The present results also suggest that special care must be devoted to the promotion of breastfeeding among lower income strata and for children with low birth weight. 


\section{Resumo}

A amamentação é fundamental para a saúde infantil. O artigo compara mudanças na duração da amamentação em três coortes de nascimentos, de 1982, 1993 e 2004, na cidade de Pelotas, Rio Grande do Sul. Amostras das coortes de 1982 e 1993 e todas as crianças da coorte de 2004 foram visitadas em casa em torno de 12 meses de idade. Foram investigados a duração da amamentação e o momento em que diferentes tipos de alimentos foram introduzidos na dieta regular. A duração mediana da amamentação aumentou de 3,1 para 6,8 meses ao longo do período. O aleitamento exclusivo aos três meses era praticamente inexistente em 1982, mas alcançou um terço dos lactentes em 2004. O aumento foi mais expressivo a partir de 1993, sugerindo um impacto importante das atividades de promoção. Até aproximadamente 6-9 meses, a amamentação era mais prevalente em famílias de renda mais alta, mas depois dessa idade passava a ser mais comum entre famílias mais pobres. Crianças com baixo peso ao nascer apresentavam menor duração de amamentação. A duração da amamentação está aquém das recomendações internacionais, o que justifica a realização de mais campanhas nesse sentido. Deve-se concentrar mais atenção nos recém-nascidos de baixo peso e naqueles de famílias de baixa renda.

Aleitamento Materno; Bem-Estar da Criança; Estudos de Coortes

\section{References}

1. Victora CG, Smith PG, Vaughan JP, Nobre LC, Lombardi C, Teixeira AM, et al. Evidence for protection by breast-feeding against infant deaths from infectious diseases in Brazil. Lancet 1987; 2:319-22.

2. Effect of breastfeeding on infant and child mortality due to infectious diseases in less developed countries: a pooled analysis. WHO Collaborative Study Team on the Role of Breastfeeding on the Prevention of Infant Mortality. Lancet 2000; 355:451-5.

3. Howie PW. Breastfeeding: a natural method for child spacing. Am J Obstet Gynecol 1991; 165(6 Pt 2):1990-1.

4. World Health Organization. Contemporary patterns of breast-feeding: report on the WHO Collaborative Study on Breast-feeding. Geneva: World Health Organization; 1981.

5. WHO Multicentre Growth Reference Study Group. WHO Child Growth Standards based on length/ height, weight and age. Acta Paediatr Suppl 2006; 450:76-85.

6. Horta BL, Bahl R, Martines JC, Victora CG. Evidence on the long-term effects of breastfeeding: systematic reviews and meta-analyses. Geneva: World Health Organization; 2007.

\section{Contributors}

C. G. Victora designed the research question, supervised the analysis and interpretation of the findings as well as wrote the first draft of the article. A. Matijasevich conducted the analysis and with I. S. Santos, A. J. D. Barros, B. L. Horta and F. C. Barros contributed to the interpretation of the analyses and assisted with the editing of the article.
7. Jones G, Steketee RW, Black RE, Bhutta ZA, Morris SS. Bellagio Child Survival Study Group. How many child deaths can we prevent this year? Lancet 2003; 362:65-71.

8. Venâncio SI, Monteiro CA. A tendência da prática da amamentação no Brasil nas décadas de 70 e 80. Rev Bras Epidemiol 1998; 1:40-9.

9. Rea MF. A review of breastfeeding in Brazil and how the country has reached ten months' breastfeeding duration. Cad Saúde Pública 2003; 19 Suppl 1: S37-45.

10. Barros AJD, Santos IS, Matijasevich A, Araújo CL, Gigante DP, Menezes AMB, et al. Methods used in the 1982, 1993 and 2004 birth cohort studies from Pelotas, Rio Grande do Sul State, Brazil, and a description of the socioeconomic condictions of participants' families. Cad Saúde Pública 2008; 24 Suppl 3:S371-80.

11. World Health Organization/The United Nations Children's Fund. Innocenti Declaration on the Protection, Promotion and Support of Breastfeeding. Florença: World Health Organization/United Nations Children's Fund; 1990. 
12. Bem-Estar Familiar no Brasil. Pesquisa nacional sobre demografia e saúde 1996. Brasil. Rio de Janeiro: Bem-Estar Familiar no Brasil/Macro International; 1997.

13. Ministério da Saúde. Pesquisa de prevalência de aleitamento materno nas capitais brasileiras e no Distrito Federal - PPAM-CDF, 1999. Brasília: Secretaria de Políticas de Saúde, Ministério da Saúde; 2000.

14. Victora CG, Fuchs SC, Flores JA, Fonseca W, Kirkwood B. Risk factors for pneumonia among children in a Brazilian metropolitan area. Pediatrics 1994; 93(6 Pt 1):977-85.

15. Victora CG. Exclusive breastfeending: the value of exclusive breastfeending in the first four to six mouths of life in being increasingly recognised. Dialogue on Diarrhoea 1992; (49):2.

16. Rea MF. The Brazilian National Breastfeeding Program: a success story. Int J Gynaecol Obstet 1990; 31 Suppl 1:79-82.

17. Rea MF, Berquo ES. Impact of the Brazilian national breast-feeding programme on mothers in greater São Paulo. Bull World Health Organ 1990; 68:365-71.

18. Victora CG, Barros FC, Vaughan JP. Epidemiologia da desigualdade: um estudo longitudinal de 6.000 crianças brasileiras. 2a Ed. São Paulo: Editora Hucitec; 1988.
19. Barros FC, Victora CG, Vaughan JP. Breastfeeding and socioeconomic status in Southern Brazil. Acta Paediatr Scand 1986; 75:558-62.

20. Scott JA, Aitkin I, Binns CW, Aroni RA. Factors associated with the duration of breastfeeding amongst women in Perth, Australia. Acta Paediatr 1999; 88:416-21.

21. United Nations Children's Fund. Breast-feeding and health: assignment children. Geneva: United Nations Children's Fund; 1981.

22. Santos IS, Menezes AMB, Mota DM, Albernaz EP, Barros AJD, Matijasevich A, et al. Infant mortality in three population-based cohorts in Southern Brazil: trends and differentials. Cad Saúde Pública 2008; 24 Suppl 3:S451-60.

23. Matijasevich A, Cesar JA, Santos IS, Barros AJD, Dode MASO, Barros C, et al. Hospitalizations during infancy in three population-based studies in Southern Brazil: trends and differentials. Cad Saúde Pública 2008; 24 Suppl 3:S437-43.

24. Victora CG, Vaughan JP, Barros FC, Silva AC, Tomasi E. Explaining trends in inequities: evidence from Brazilian child health studies. Lancet 2000; 356:1093-8.

25. Jeliffe DB, Jeliffe EP. Human milk in the modern world. Oxford: Oxford Medical Publications; 1979.

26. Pérez-Escamilla R. Breastfeeding and the nutritional transition in the Latin American and Caribbean Region: a success story? Cad Saúde Pública 2003;19 Suppl 1:S119-27.

Submitted on 29/Mar/2007

Final version resubmitted on $07 /$ Nov/2007

Approved on 09/Jan/2008 